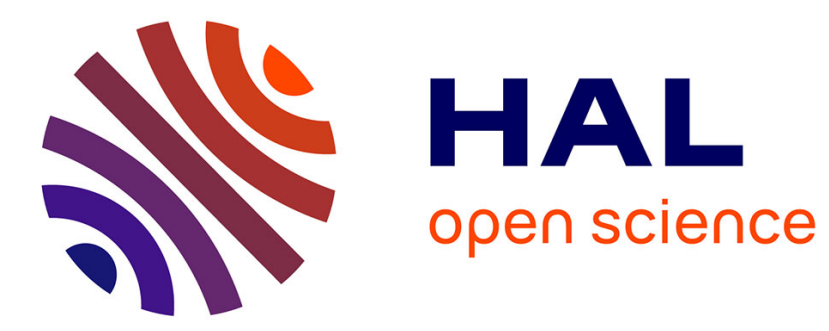

\title{
Information Logistics Means to Support a Flexible Production?
}

\author{
Susanne Altendorfer-Kaiser
}

\section{To cite this version:}

Susanne Altendorfer-Kaiser. Information Logistics Means to Support a Flexible Production?. IFIP International Conference on Advances in Production Management Systems (APMS), Sep 2015, Tokyo, Japan. pp.414-421, 10.1007/978-3-319-22756-6_51 . hal-01417521

\section{HAL Id: hal-01417521 \\ https://hal.science/hal-01417521}

Submitted on 15 Dec 2016

HAL is a multi-disciplinary open access archive for the deposit and dissemination of scientific research documents, whether they are published or not. The documents may come from teaching and research institutions in France or abroad, or from public or private research centers.
L'archive ouverte pluridisciplinaire HAL, est destinée au dépôt et à la diffusion de documents scientifiques de niveau recherche, publiés ou non, émanant des établissements d'enseignement et de recherche français ou étrangers, des laboratoires publics ou privés. 


\title{
Information logistics Means to support a flexible production?
}

\author{
Dr. Susanne Altendorfer-Kaiser \\ Industrial Logistics, Montanuniversitaet Leoben, Austria \\ susanne.altendorfer@unileoben.ac.at
}

\begin{abstract}
The information economy is characterized by an excessive supply of data and information, which makes it difficult to establish an optimal information management. Therefore, this paper deals with the challenge of how an efficient information logistics can be established. An approach using the lean philosophy for identification and categorization of information is presented. The paper concludes with the importance of Information logistics and how lean information flows support a flexible production.
\end{abstract}

Keywords: information flow, information systems, muda, production

\section{Background}

Under the theme Industry 4.0 the manufacturing industry, especially in Germany and Austria, works on the creation of increasingly intelligent, autonomous and decentralized subsystems that should lead to more competitive production and logistics processes. Therefore the effective and economical integration of information and decision-making bodies is relevant. If this integration is efficiently performed on all system and corporate levels this can be the key success factor.

Despite the increased use of currently available technologies such as RFID or semi-autonomous control of production and logistics facilities the immediate intraand inter-company transfer of information along the supply chains is often very limited. However in times of growing competitiveness and shorter times-to-market an efficient and cost-optimized material flow can arise only through the sophisticated integration of production and information processes. Thus, the collection and use of information is of increasingly importance.

Due to recent developments and trends such as Industry 4.0, Big Data, Data Analytics data and/or information is omnipresent. This apparent advantage can be quickly turned into a drawback: there is an oversupply of data that are not beneficial information to their environment and this also includes more disadvantages than potential for a company. This flood of data means that the truly relevant information may not be located at the time needed.

Just by the strong interconnectedness, availability and information overload, it is essential for companies to have the right information at the right time in the right form at the right place for the right person. $[2,18]$

adfa, p. 1, 2011.

(C) Springer-Verlag Berlin Heidelberg 2011 
This aspect, however, is still often underestimated as the subject of information is still very strong anchoring purely in the IT department. Here, the data management is the main focus during the transformation of the physical data. It would be just a strategic necessity for companies to bring the information flows with the material flows in harmony. Information and communication technologies (ICT) are here a key technology in order to targetly embed the information flows with the production processes. [17] However, the importance of ICT is not yet completely defined precisely in the area of information logistics and still in science there are different views.

Therefore this paper deals with the importance of Information logistics and how lean information flows support a flexible production.

\section{Terms and Definitions}

The competitiveness of companies in the future is strongly influenced by the way they do business. Here, knowledge becomes an integral production factor. And knowledge is based on information. Nowadays information is omnipresent - it is the time of the so-called information society. Not only in our private lives we are confronted with information also the daily business is formed by an information overload.

Especially for companies the right information at the right time is nowadays a crucial asset. Barney defines information as one resource (among others) that enables "the firm to conceive of and implement strategies that improve its efficiency and effectiveness" [3]. Nevertheless it is not the quantity that is important. It is the quality of information that comes into value.

Here Floridi defined the general definition of information (GDI) as a tripartite way: $\sigma$ is an instance of information, as semantic context, if:

- (GDI.1) $\sigma$ consists of one or more data;

- (GDI.2) the data in $\sigma$ are well-formed;

- (GDI.3) the well-formed data in $\sigma$ are meaningful [5].

In order to talk about the quality of information in general and for logistics in particular, it is important at this point to define the terms data, information and knowledge, to connect information and logistics in a more appropriate way.

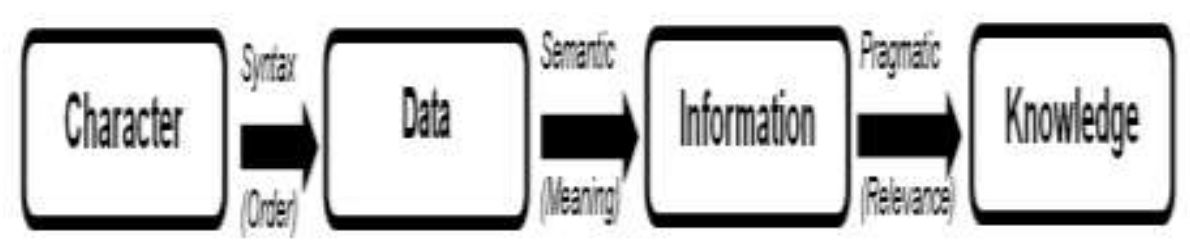

Fig. 1. Interconnection between data, information and knowledge 1 
- Data: The noun data is defined as facts and statistics collected together for reference or analysis. The term itself comes from the Latin plural of "datum".

- Information: For this paper the relevant definition of information is defined as something that is conveyed or represented by a particular arrangement or sequence. The term information origins in the Latin verb "informare" (in English" to inform"), which means 'to give from' or 'to form an idea of'. Furthermore the Latin noun "informatio" had already had the meaning of concept and idea".

- Knowledge: Knowledge comes from the verb "to know", which is of Germanic origin. Knowledge means facts, information, and skills acquired through experience or education and can refer to theoretical and practical understanding of a subject. Furthermore it can be divided between implicit and explicit knowledge.

Especially data, its generation, storage and use in form of information is essential for the material flow (illustrated in Fig.2).

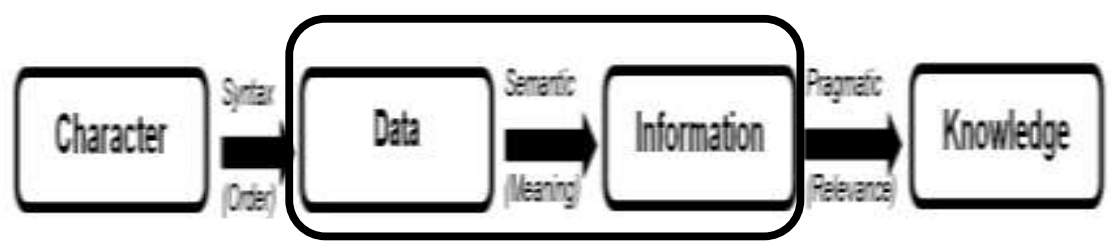

Fig. 2. Important areas of the information logistics for the material flow $[1,6]$

Nevertheless, the importance of information and related information and communication technologies must be recognized for logistics and their benefit aspects of logistics must be placed in the foreground. Current developments in the field of auto-ID technologies and cyber-physical systems provide high potential for the logistics area, but can only be used up completely when both the logistics and the information relevant factors are considered. Only through an appropriate symbiosis of information and material flows can be directing support the logistics, according to the principle "IT enables business" [12]. Therefore, it is desirable to consider the information logistics as a design element and give it an appropriate role in logistics.

\section{Information Flow Management for Information Logistics}

Nowadays information is omnipresent - it is the time of the so-called information society. Especially for companies the right information at the right time is nowadays a crucial asset. Barney defines information as one resource (among others) that enables "the firm to conceive of and implement strategies that improve its efficiency and effectiveness" [3]. Nevertheless it is not the quantity that is important. It is the quality of information that comes into value. But it is not only the quality of information that matters. What's even as important is that the information is at the right time at the right place. Here the six R's of logistics matter for the proper information flow management.

The following table shows the six R's of logistics applied on information. [2] 
Table 1. 6 R's of Logistics applied on Information [2]

\begin{tabular}{|l|l|}
\hline R's & Information context \\
\hline Right Information & Necessary for the user \\
\hline Right Time & Decision-supportive \\
\hline Right Quantity & As much as necessary \\
\hline Right Place & Accessible for the user \\
\hline Right Quality & Detailed enough and usable \\
\hline Right Costs & Reasonable Price \\
\hline
\end{tabular}

To support the realisation of an adequate information flow management within the company, the concept of IT as enabler of process change is still on the forefront although dates already back to [4] and [7]. A change in information systems is possible as the technological progress over the years has opened new possibilities to support the organizational reengineering. However, information system aspects have often been left out of consideration in reengineering projects. Information systems often have had and still have the status of being a matter of course and therefore their integration is often not thoroughly considered [8]. Thus companies are far too often behind in their information technologies. Software systems are often out-dated and poorly structured. The need for agile software architecture to support IFM becomes evident when the need for more flexibility and reduced costs in the daily business urges companies to restructure.

Martin defines a company as an open, socio-technical system with an organisation that has the goal to supply its customers in a satisfactorily way and by doing so making profit [9]. As open system it has a lot of interfaces to the outside world, as shown in Fig. 3.

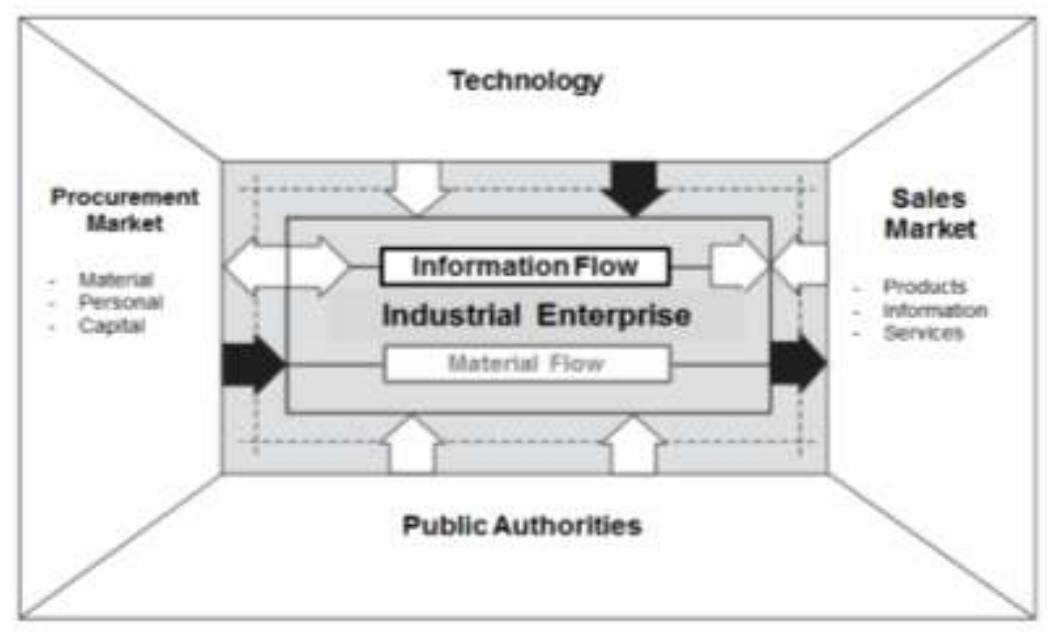

Fig. 3. Interfaces of a Company [translated to English based on [10]] 
Highlighted in this figure is the information flow, which runs in parallel to the material flow. This already shows the importance of a defined information flow and a well established information flow management. And an IFM is not only necessary for intra-company flows but also for the whole supply chain. Vogt puts a lot of weight on the importance of information along the supply chain: „Information regarding the demand for, quality of the products, and other factors such as financing, and guarantees, will flow up and down the supply chain to keep every member informed of the current state of affairs pertaining to their products. This information must be timely and accurate as the manufacturing of the products must be adjusted to the demand as quickly as possible" [13].

\section{$4 \quad$ Identification of relevant Information - Impossible?}

Information logistics has many parallels to the production logistics. Thus, the logistical principle of "6R" can be applied to the information and the information life cycle can certainly see similarities with the product life cycle.

With the life-cycle model for information it is possible to identify which phases information pass through.

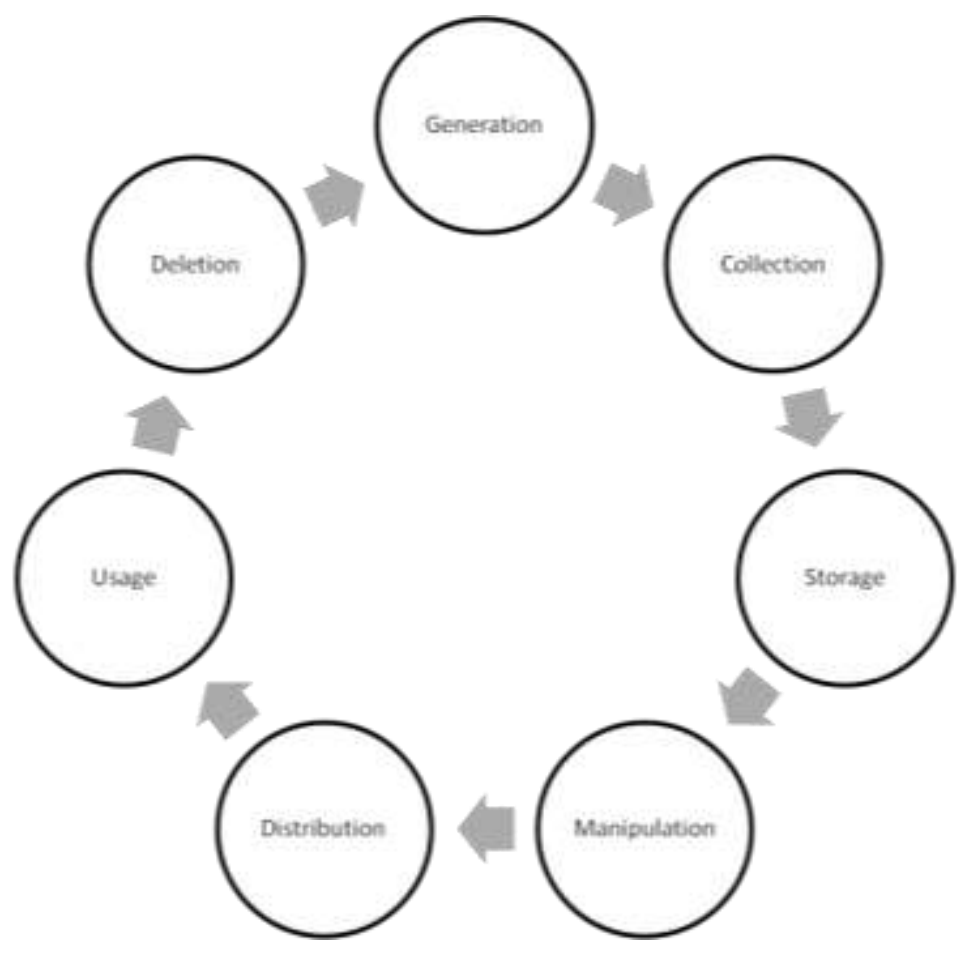

Fig. 4. Information Life Cycle (developed after the product life cycle [19]) 
In a further step, corresponding tasks can be defined and assigned to appropriate technologies for the realization of the individual phases. (This aspect however is not addressed in this paper)

What is, however, treated in the literature very little, are the ways to stem the flood of information by controlling the information life cycle and make a categorization of value-added and non-value-added information. Therefore, in this section an opportunity is presented in the context of production management to identify relevant information.

The car manufacturer Toyota achieved to stabilize the organization through a targeted focus on the prevention of waste in the production process, resulting in high quality products resulted. The resulting strategies and methods to eliminate internal waste (Muda) helped Toyota in the 1970s and 1980s [7]. Considering the current process structure of modern enterprises certain parallels between production and information processes in terms of avoiding waste can be drawn. Modern hardware and software solutions promise greater transparency and increased efficiency through the collection and analysis of numerous data. However, due to the high density of information it is often difficult to assess them according to their percentage of completion. The apparent security to hoard all the relevant data proves in many cases than risk losing sight of what is essential. Omnipresent media such as the Internet allow an enterprise-wide manipulation, which on one hand is a significant advantage of modern technology, but on the other hand also enhances the potential for informationrelated waste. For this reason, it requires a strict editing and plausibility check of information, which can be created by the definition of cross-company practices. As a basis for the establishment of such standards, the detection and localisation of wastes might be used. Therefore, an attempt is made based on Chapados [20] to transfer the types of waste as defined by Taiichi Ohno [21] within production to waste types of information.

Table 2. Muda of Information compared to Muda of Production [21]

\begin{tabular}{|l|l|}
\hline Muda of Production & Muda of Information \\
\hline Over Production & Production of wrong information \\
\hline Idle Times & Delay in the information retrieval \\
\hline Transport & To many interfaces \\
\hline Production & $\begin{array}{l}\text { No clear definition what kind of infor- } \\
\text { mation is needed }\end{array}$ \\
\hline Movements & High effort of transformation \\
\hline Stock & Inefficient storage \\
\hline Maintenance & Missing or wrong information \\
\hline
\end{tabular}

The resulting "Muda of information" should identify the main causes of a possible "Over informatisation" so as to identify targets for efficient data management. It was also discussed explicitly in addition to usually quickly identifiable wastes to those shapes that result from previous errors. One example for this is the inefficient allocation of access rights. But also the involvement of too many interfaces contributes 
negatively to the overall efficiency of the information process and thus to inefficiency of the overall process. The success of this, at first trivial-sounding approach is, however, boycotted by several sites as compared to the outdated structures or nonacceptance of the user. Therefore, the industrial desensibilisation to information processes and media must be pursued. The creation of common structures and standards represents a proven form to reduce and prevent information-related wastes.

\section{$5 \quad$ Conclusion and Outlook}

Information Logistics has a great potential to support the processes of a company and the whole production area. Especially initiatives like cyber-physical systems, Internet of Things and Industry 4.0 are strongly heading in the direction of smart factory and horizontal and vertical integration along the supply chain. At this point information logistics will be an essential cornerstone. With the ongoing research we will strongly investigate on the information flow management and the necessary methods and techniques for information logistics.

This paper highlights information as becoming increasingly important and targeted identification and categorization of the information would be necessary. Therefore, it is essential to consider information logistics as an independent and significant part of the company. A deficit in the field of information logistics is partly due to the fact that there are no uniform standards or no industry-wide reference models, such as the information logistics should best be integrated into the company and can be achieved as an ideal link between information logistics and production. Only in this way, depending on the flow of information, production can be optimized.

\section{$6 \quad$ References}

1. Auer, T.: Wissensmanagement: Reizwort oder zeitgemäße Notwendigkeit, Publikation im Controller-Leitfaden 12/2008, WEKA Verlag.2008.

2. Augustin, S.: Informationswirtschaft und Informationslogistik im Industrieunternehmen. München.1990.

3. Barney, J.: Firm Resources and Sustained Competitive Advantage. Journal of Management. 17. 1991.

4. Davenport T.: Process Innovation: Reengineering Work Through Information Technology. Harvard Business School Press. 1993

5. Floridi, L.: Information: A Very Short Introduction. Oxford University Press. 2010. p. 359.

6. Hacker, Winfried: Informationsflussgestaltung als Arbeits- und Organisationsoptimerung. Jenseits des Wissensmanagements. vdf Hochschulverlag AG an der ETH Zürich. 2007.

7. Hammer M., Champy J.: Reengineering the Corporation: A Manifesto for Business Revolution. Harpers Paperbacks. Rev Upd. 2003.

8. Kawalek J.: "Rethinking Information Systems in Organizatons. Integrating Organisational Problem Solving". Routledge. New York.2008. 
9. Martin, H.: Transport-und Lagerlogistik.Planung, Struktur, Steuerung und Kosten von Systemen der Intralogistik. Springer Vieweg.München.2011.

10. Osterloh, M., Frost,J.: Prozessmanagement als Kernkompetenz: Wie Sie Business Reengineering strategisch nutzen können (Processmanagement as Core Competence: How to strategically use Business Reengineering), Gabler Verlag, Wiesbaden, 2006.

11. Semar,W.: Weiss + Appetito Holding AG - Software für den ganzen Konzern. In: Wölfle, Ralf; Schubert, Petra (Hg.): Dauerhafter Erfolg mit Business Software - 10 Jahre Fallstudien nach der eXperience Methodik. München: Carl Hanser, S. 51-64. (2009)

12. Sundblad S., Sundblad P.2007. "Business Improvement through better architected software". Microsoft Architect Journal.

13. Vogt, JJ, Pienaar W., de Wit PWC: Business Logisitics Management: Theory and Practice. Oxford University Press. South Africa.Second Edition 2005.

14. Gudehus, T.: Logistik. Grundlagen-Strategien-Anwendungen, 4.Auflage. München 2010.

15. Winter, R.; Dinter, B.: Integrierte Informationslogistik. 2008.

16. Eversheim, W.; Luczak, H.: Industrielle Logistik, 8. Auflage. Mainz 2004.

17. Straube, F.: e-Logistik. Ganzheitliches Logistikmanagement. 2004.

18. Zsifkovits, H.: Schwerpunkte der Industrielogistik. In: WINGbusiness (2014) 4, S.12-13.

19. Schuh, G.; Schmidt, C.: Produktionsmanagement: Handbuch Produktion und Management, 2.Auflage. 2014.

20. Chiarini, A.: Lean Organization: from the Tools of the Toyota Production System to Lean Office. 2013.

21. Chapados, C: Eight wastes of Information. URL: http://toyotaproduction systemus.wordpress.com/2013/05/04/eight-wastes-muda-of-information/, Abrufdatum 10.01.2014.

22. Dahlgaard, J; Dahlgaard-Park, S: Lean production, six sigma quality, TQM and company culture. In: The TQM Magazine 18 (2006), S. 263-281. 